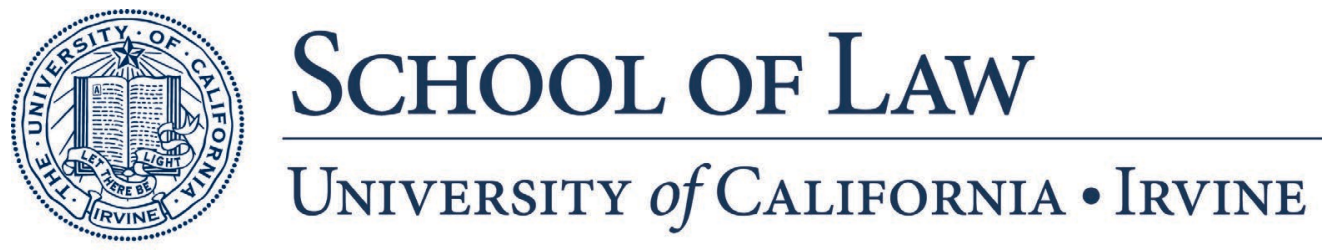

Legal Studies Research Paper Series No. 2021-12

Harmonization of Civil Procedure:

Is the United States a Model for the European Union?

(Chapter IN: From Common Rules to Best Practices is European Civil

Procedure, Burkhard Hess and Xandra E. Kramer, eds., Nomos, 2018)

Christopher Whytock

cwhytock@law.uci.edu

University of California, Irvine School of Law

The paper can be downloaded free of charge from SSRN at: 


\title{
Harmonization of Civil Procedure: Is the United States a Model for the European Union?
}

\author{
Christopher A. Whytock \\ University of California, Irvine
}

Last Author Draft; Please Cite to Published Version

\begin{abstract}
In Burkhard Hess and Xandra E. Kramer, eds., From Common Rules to Best Practices is European Civil Procedure (Nomos 2018)
\end{abstract}

Summary: It is tempting to view the United States as a model for the harmonization of rules of civil procedure. This chapter argues that there may be lessons to learn from the US experience, but that there are reasons to be skeptical about the usefulness of the US model for efforts to harmonize the procedural rules of EU members. The rules of civil procedure are not as harmonized in the United States as commonly assumed. Judicial cooperation in the United States is in any event based less on extensive harmonization than on a system of interjurisdictional deference made possible by the twin foundations of full faith and credit and minimum procedural standardsfoundations that do not yet appear to be sufficiently well developed in the EU to make this model immediately workable there. Finally, for reasons of legal and political culture, the process of making rules of civil procedure in the United States is politicized, seemingly to a greater extent than in the EU. A more technical path toward procedural harmonization might be possible, and more desirable, in the EU.

\section{(A) INTRODUCTION}

The European Union has made important progress toward the harmonization of private international law. ${ }^{1}$ Some commentators, noting gaps, redundancies and incoherencies in EU private international law, argue that the time has come to codify the field. ${ }^{2}$ Even without a codification, the progress already made is impressive, particularly from the perspective of an observer in the United States, where important parts of private international law — including interstate and international choice of law, as well as the recognition and enforcement of foreign country judgments - remains fragmented across the 50 states and the District of Columbia.

Outside the realm of "civil matters having cross-border implications" (TFEU Article 81), however, the EU's progress toward procedural harmonization has been more modest. There is no "genuine or uniform European law of civil procedure." 3 The EU's procedural laws "never touch upon the heart of civil practice, i.e. the complicated and controversial topics of fact gathering, case management, judgments, appeals and interim relief" ${ }^{4}$ and, as a result, "purely national cases

\footnotetext{
${ }^{1}$ X.E. Kramer, "Harmonisation of Civil Procedure and the Interaction with Private International Law", in X.E. Kramer and C.H. van Rhee (eds), Civil Litigation in a Globalising World, T.M.C. Asser Press, 2012, 121, at 125.

${ }^{2}$ G. Rühl and J. von Hein, "Towards a European Code on Private International Law?", 79 RabelsZ (2015) 701.

${ }^{3}$ B. Hess, "Procedural Harmonization in European Context", in X.E. Kramer and C.H. van Rhee (eds), Civil Litigation in a Globalising World, T.M.C. Asser Press, 2012, at 161; M. Eliantonio, "The Future of National Procedural Law in Europe: Harmonisation vs. Judge-made Standards in the Field of Administrative Justice”, 13 EJCL (2009) 1, at 2, http://www.ejcl.org/133/art133-4.pdf.

${ }^{4}$ G. Wagner, "Harmonisation of Civil Procedure: Policy Perspectives", in X.E. Kramer and C.H. van Rhee (eds), Civil Litigation in a Globalising World, T.M.C. Asser Press, 2012, at 118.
} 
continue to be governed by the rules of civil procedure of the Member State where the case is brought." 5

For some observers, this is not a satisfactory situation. From the Storme Report in 1994, which "triggered the debate on the possibility and the pros and cons of procedural harmonisation," the European Law Institute-UNIDROIT project on "From Transnational Principles to European Rules of Civil Procedure," and from scholarly conferences dealing with harmonization of European procedural law $^{7}$ to the report of the European Parliamentary Research Service on the Europeanisation of civil procedure, ${ }^{8}$ there is now serious academic and policy discussion about the harmonization of European civil procedure. Hess ${ }^{9}$ argues that "there is a compelling need for a more coherent and systematic legislative approach" and that the long term goal should be "the elaboration of an 'umbrella instrument' providing for a coherent and systematic set of rules of European procedural law."

It is tempting to view the United States as a model for such an endeavor. As others have observed, a harmonizing impulse has characterized much of the history of US civil procedure, ${ }^{10}$ resulting in a considerable degree of harmonization across US states and between the state and federal judiciaries. ${ }^{11}$ One might analogize the US experience to the EU's own harmonization project and conclude that a US perspective can offer insights for how the EU might harmonize its own rules of civil procedure. ${ }^{12}$

There may indeed be lessons to learn from the US experience. In this chapter, however, I argue that there are at least three reasons to be skeptical about the usefulness of the United States as a model for the harmonization of procedural rules in the EU.

First, the rules of civil procedure are not as harmonized in the United States as commonly assumed (C). The rules diverge considerably across the judiciaries of different US states, within the federal judiciary, and between state judiciaries and the federal judiciary. If the United States, with over 200 years of history and a common legal tradition, has not reached the goal of harmonization, how likely is it that the EU, with a much shorter history and diverse legal traditions, will attain that goal by using the US experience as a model?

Second, judicial cooperation in the United States is based less on extensive harmonization than on a system of interjurisdictional deference made possible by the twin foundations of full faith and credit and minimum procedural standards (D). However, it is unclear that either of these

\footnotetext{
${ }^{5}$ C.H. van Rhee, "Harmonisation of Civil Procedure: An Historical and Comparative Perspective", in X.E. Kramer and C.H. van Rhee (eds), Civil Litigation in a Globalising World, T.M.C. Asser Press, 2012, at 54.

${ }^{6}$ van Rhee, supra n. 5, at 56.

${ }^{7}$ X.E. Kramer and C.H. van Rhee, "Civil Litigation in a Globalising World: An Introduction in Civil Litigation", in X.E. Kramer and C.H. van Rhee (eds), Civil Litigation in a Globalising World, T.M.C. Asser Press, 2012, 1.

${ }^{8}$ R. Mańko, Europeanisation of Civil Procedure: Towards Common Minimum Standards?, European Parliamentary Research Service (PE 559.499), 2015.

${ }^{9}$ Hess, supra n. 3, at 171 .

${ }^{10}$ T. Main, "Procedural Uniformity and the Exaggerated Role of Rules", 46 Vill.L.Rev. (2001) 311.

${ }^{11}$ P. Dubinsky, "United States: Harmonisation and Voluntarism. The Role of Elites in Creating an Influential National Model, the Federal Rules of Civil Procedure”, in X.E. Kramer and C.H. van Rhee (eds), Civil Litigation in a Globalising World, T.M.C. Asser Press, 2012, 223.

${ }^{12}$ Kramer and van Rhee, supra n. 7, at 15.
} 
foundations is sufficiently well established in the EU today to ensure a degree of judicial cooperation among EU member states that matches that which exists among US states.

Third, for reasons of legal and political culture, the process of making rules of civil procedure in the United States is politicized, seemingly to a greater extent than in the EU (E). A more technical approach might be possible, and more desirable, in the EU.

\section{(B) From the English Tradition to a United States Model}

The starting point for understanding US civil procedure is English civil procedure. The English system distinguished actions at law, with highly technical forms of action and decisions based on legal precedent, and actions at equity, with their own procedure and with decisions based on equitable considerations. ${ }^{13}$ Naturally, the English model strongly influenced the early United States. However, the influence was not uniform. After independence, some states (such as Delaware, New Jersey and New York) had separate courts of law and equity; some states (such as Connecticut and New Hampshire) had a single court with separate law and equity branches, as did the newly created US federal courts; and some states (such as Massachusetts and Pennsylvania) did not initially have courts with equity jurisdiction. ${ }^{14}$ The states (and the federal government) developed their judicial systems separately, leading to significant procedural divergence; ${ }^{15}$ but they nevertheless shared a common legal tradition, which surely facilitated the harmonization efforts to come.

There has never been a centralized federal legislative attempt to impose a single set of rules of civil procedure on the US states (in fact, the federal government does not have the constitutional authority to do so) - so the history of inter-state procedural harmonization is largely a story of state adoption of model rules, a process that Dubinsky ${ }^{16}$ has called "voluntarism." There have been two significant models for the US states: the Field Code and the Federal Rules of Civil Procedure.

The first significant move toward procedural harmonization in the United States came with the socalled Field Code, adopted as legislation by New York in 1848 and named after its primary advocate, the lawyer David Dudley Field. The Field Code simplified civil procedure, abolishing the distinction between law and equity and establishing a single form of action - the civil action - in which a plaintiff would plead the facts needed to establish the elements of a cause of action or defense. By 1900, although US procedure was far from harmonized, twenty-seven states had adopted codes of procedure based wholly or partially on the Field Code. ${ }^{17}$

Meanwhile, in the US federal courts, there was a mix of diversity and uniformity. In actions at law, the Process Act of 1789 and later the Conformity Act of 1872 required the federal courts to follow the procedural law of the states in which they sat, whereas for actions at equity the Supreme Court developed uniform federal rules (modeled largely on English practice). The result was that aside from equity rules in the federal courts, there was considerable procedural diversity in the United States through the early 1900s, such that "a lawyer practicing in the state and federal courts of a particular locality must have mastered three systems of procedure: the state procedure (which

\footnotetext{
${ }^{13}$ G. Hazard, J. Leubsdorf, and D.L. Bassett, Civil Procedure, 6th ed., Foundation Press, 2011, at 12-20.

${ }^{14}$ K. Clermont, Principles of Civil Procedure, 3rd ed., West, 2012, at 31-32.

${ }^{15}$ R. Marcus, "Modes of Procedural Reform”, 31 Hastings Int'l \& Comp.L.Rev. (2008), at 163-164.

${ }^{16}$ Dubinsky, supra n. 11, at 226.

${ }^{17}$ Hazard, Leubsdorf and Bassett, supra n. 13, at 21-22.
} 
might be unmerged and therefore comprise two [i.e. law and equity] procedures); the federal lawprocedure (which was the state procedure in law actions...); and the federal equity-procedure." 18

With the Rules Enabling Act of 1934, the US Congress authorized the US Supreme Court to make rules of procedure for the US federal courts. An Advisory Committee for the Federal Rules of Civil Procedure was established to draft the rules, which were approved by the Supreme Court and submitted to Congress. They entered into effect in 1938, providing a single set of procedural rules for all civil claims in the US federal courts. Among other features, the Federal Rules of Civil Procedure merged law and equity and provided simple and flexible rules of pleading, procedures for joinder of parties and claims, and comprehensive rules for discovery. Harmonization of procedure in the US federal courts had, in theory, been achieved - at least temporarily. The Federal Rules also contributed to the further harmonization of procedure across US state courts, as a significant number of states used them as a model for their own procedural reforms. ${ }^{19}$

Although it is difficult to identify a particular highpoint of procedural harmonization in the United States, one might place it sometime in the 1960s, by which point the Federal Rules applied in all civil actions across the 94 districts of the US federal courts, and sixteen states plus Puerto Rico had rules of civil procedure "substantially similar" to the federal rules, ${ }^{20}$ or perhaps in the 1970 s. $^{21}$ However, according to one estimate, more states followed the Field Code in 1897 than have ever followed the Federal Rules. ${ }^{22}$

\section{(C) The Limits of Procedural HaRmonization IN THE US}

For outside observers, the story of US civil procedure sometimes stops here, leaving the impression of an essentially harmonized US system of civil procedure. To be sure, from an external perspective, one might justifiably perceive the existence of a coherent "American approach" to civil justice: As Dubinsky ${ }^{23}$ puts it:

[T]here exists today much similarity in the rules of civil procedure throughout the United States. A civil jury trial in state court in Iowa is much like one in federal court in Florida. Joinder of parties and consolidation of claims is common in all judicial systems in the U.S. The right of litigants to pursue pre-trial discovery of documents and testimony (even from non-parties) is extensive everywhere in the U.S., at least when compared to evidence gathering in other countries. The approach to the financing of litigation - contingency fee agreements, presumptions against shifting attorneys' fees, very little public funding — varies only marginally as one moves from one state to another.

\footnotetext{
${ }^{18}$ Clermont, supra n. 14 , at 34-35.

${ }^{19}$ Dubinsky, supra n. 11, at 223-245.

${ }^{20}$ C. A. Wright, "Procedural Reform in the States", 24 F.R.D. (1960), at 87.

${ }^{21}$ G. Koppel, "Toward a New Federalism in State Civil Justice: Developing a Uniform Code of State Civil Procedure through a Collaborative Rule-Making Process", 58 Vand.L.Rev. (2005), at 1170; C. Tobias, "Civil Justice Reform and the Balkanization of Federal Civil Procedure", 24 Ariz.St.L.J. (1992), at 1395; data from J. Oakley and A. Coon, "The Federal Rules in State Courts: A Survey of State Court Systems of Civil Procedure", 61 Wash.L.Rev. (1986), at 1367-1427.

${ }^{22}$ S. Subrin, "Federal Rules, Local Rules, and State Rules: Uniformity, Divergence, and Emerging Procedural Patterns", 137 U.Pa.L.Rev. (1989), at 2044.

${ }^{23}$ Dubinsky, supra n. 11, at 227.
} 
But while there may be more diversity in the rules of civil procedure across EU member nations than across US states (and between the US federal judiciary and US state judiciaries), it is important not to exaggerate the extent of US harmonization. ${ }^{24}$ If the US model is going to be used as one point of reference for deliberating on plans for harmonization elsewhere, it is important to have a more nuanced understanding that accounts for three dimensions of persistent (and some would say increasing) procedural diversity in the United States: diversity across US states, diversity across federal judicial districts, and diversity between state and federal courts, even in the same state.

\section{(1) Procedural Diversity Across US States}

Two systematic surveys, one by Oakley and Coon in 1986 and another by Oakley in 2003, offer an empirical snapshot of the extent of diversity across US states. The 1986 survey revealed the following: 25

- 23 jurisdictions (22 states plus the District of Columbia) were so-called "replica jurisdictions," with rules of civil procedure that replicated the Federal Rules of Civil Procedure.

- 3 states had rules that varied slightly from the Federal Rules, but were clearly modeled on the Federal Rules.

- 4 states, unlike the federal system, adopted rules in a statutory code, but those rules closely followed the Federal Rules.

- 3 states had rules that largely replicated the Federal Rules, except for the basic rules of pleading.

- 18 states had procedural systems that were "substantially dissimilar" from the Federal Rules, including highly populous states such as California, Florida, Illinois, New York and Texas.

The authors found that while the majority of jurisdictions conformed substantially to the Federal Rules, those jurisdictions encompassed only a minority of the US population. Sixty-two percent of the population lived in states with rules of civil procedure that were substantially dissimilar from the Federal Rules. They also studied the pace of state adoption of rules based on the Federal Rules, and found that the rate of replication was on the decline: between 1949 and 1975, the number of replica jurisdictions rose from 4 to 23, but from 1975 to 1985 no state followed suit.

Based on these results, the authors concluded that "only a minority of states have embraced the system and philosophy of the Federal Rules wholeheartedly enough to permit classification as true federal replicas." 26 According to the authors, "the era of an 'accelerating trend' of state court reform of civil procedure in the image of the Federal Rules has ended." 27

The 2003 survey provided evidence suggesting that the harmonizing trend had not only slowed, but indeed reversed itself. The survey focused on a sample of significant amendments to the

\footnotetext{
${ }^{24}$ See Oakley and Coon, supra n. 21, at 1427 (cautioning "against exaggeration of the dominance of the Federal Rules in modern American state courts").

${ }^{25}$ Oakley and Coon, supra n. 21, at 1367-1427.

${ }^{26}$ Oakley and Coon, supra n. 21, at 1369.

${ }^{27}$ Oakley and Coon, supra n. 21, at 1427.
} 
Federal Rules between 1980 to 2000. It then determined how the 33 jurisdictions from the 1986 survey that were substantially similar to the Federal Rules responded to amendments to these rules: five in 1980-1991 (dealing with discovery, lawyer certification of pleadings and other court filings, pretrial case management, subpoenas, and judgment as a matter of law), seven amendments in 1993 (dealing with service of process, lawyer certification of pleadings and other court filings, pretrial case management, mandatory disclosures, and discovery), and one amendment in 2000 (dealing with mandatory disclosures). The survey revealed the following adoption rates:

- $62 \%$ for the 1980-1991 amendments: 102 out of 165 opportunities to adopt (5 amendments multiplied by 33 jurisdictions).

- $28 \%$ for the 1993 amendments: 65 out of 231 opportunities to adopt (7 amendments multiplied by 33 states).

- 42\% (overall rate from 1980-1993, 12 amendments).

- $6 \%$ for the 2000 amendment: 2 out of 33 opportunities to adopt (1 amendment multiplied by 33 states).

- $39 \%$ (overall rate through 2000, 13 amendments).

Based on these results, Oakley concluded that "[n]ot only has the trend toward state conformity to the federal rules stopped accelerating - it has substantially reversed itself" and that "[f]ederal procedure is less influential in state courts today than at any time in the past quarter-century." 28 Oakley speculated about the "causes for the decline of state conformity to the federal model," suggesting that the increasing divergence is due less to states reverting back to pre-Federal Rules models than to states declining not to follow "dubious" amendments to the Federal Rules. ${ }^{29} \mathrm{He}$ observed that "from a state perspective, the [Federal Rules] have lost credibility as avatars of procedural reform." ${ }^{30}$ In short, "[i]t is the Federal Rules that appear to have moved away from the states, rather than vice versa." ${ }^{31}$ The trend may be due in part to the number of amendments to the Federal Rules and the controversial nature of many of them. ${ }^{32}$

One of the most important changes in US procedure since the adoption of the Federal Rules of Civil Procedure is the change in federal pleading standards adopted not through the federal rulemaking process or through legislation, but directly by the US Supreme Court in two cases: Bell Atlantic Corp. v. Twombly (2007) and Ashcroft v. Iqbal (2009). In these cases, the Supreme Court abandoned the "notice standard" of pleading in favor of a stricter "plausibility standard" of pleading which, according to some critics, improperly changed the rules without following the legally established procedures for doing so. The question for the states, which are not bound by these decisions, is whether to change their pleading standards to conform to the Twombly/Iqbal standard. Already, this development is leading to further differences across states as some of them reject and some of them adopt the new federal plausibility pleading standard. ${ }^{33}$

\footnotetext{
${ }^{28}$ J. Oakley, "A Fresh Look at the Federal Rules in State Courts", 3 Nev. L.J. (2003), at 355.

${ }^{29}$ Oakley, supra n. 28, at 359.

${ }^{30}$ Oakley, supra n. 28, at 355.

${ }^{31}$ Oakley, supra n. 28, at 359.

${ }^{32}$ C. Tobias, "The Past and Future of the Federal Rules in State Courts", 3 Nev. L.J. (2003), 403.

${ }^{33}$ As of 2014, of the 33 states with rules based on the Federal Rules as identified by Oakley and Coon, supra n. 21, so far 4 have adopted the plausibility pleading standard, 8 have rejected it, and 18 have yet to address the question. J. Sullivan, "Do the New Pleading Standards Set Out in Twombly and Iqbal Meet the Needs of the Replica Jurisdictions?", 47 Suffolk U.L.Rev. (2014), at 70; Z.W.J. Chen, "Following the Leader: Twombly, Pleading Standards, and Procedural Uniformity", 108 Colum.L.Rev. (2008),
} 
In short, there is considerable procedural diversity across US states. As one commentator has summarized the situation, "The 'top-down' rules model for achieving inter-state uniformity has failed." 34

\section{(2) Procedural Diversity within the Federal System}

There also is procedural diversity within the US federal judiciary, across the 94 federal judicial districts. Although uniformity in federal civil procedure generally prevailed during the thirty years following the adoption of the Federal Rules of Civil Procedure in 1938, this began to change in the 1970s. Already in 1985, one scholar had referred to "The Myth of Uniformity in Federal Civil Procedure." 35

This decline in harmonization is due primarily to the proliferation of local federal rules of civil procedure. ${ }^{36}$ Rule 83 of the Federal Rules authorizes each federal district court, by a majority of its judges, to adopt local rules consistent with federal statutes and the Federal Rules of Civil Procedure. In addition, it authorizes individual judges to "regulate practice in any manner consistent with federal law, [the Federal Rules], and the district's local rules." ${ }^{37}$ Although the drafters "apparently envisioned that districts would sparingly invoke Rule 83," 38 this has not proved to be the case.

According to a study released in 1989, the federal district courts had already issued more than 5,000 local rules and many of them conflicted with the Federal Rules. Almost every district had local rules governing pretrial procedure, including pretrial conferences and discovery. Moreover, at the level of individual judges, the study found numerous "standing orders" governing procedure. ${ }^{39}$ With the passage of the Civil Justice Reform Act in 1990, the US Congress directly contributed to de-harmonization by directing the federal districts to develop and implement their own measures to reduce litigation expense and delay. ${ }^{40}$ There also is increasing diversity in

at 1431-1470; R. Michalski, "Tremors of Things to Come: The Great Split between Federal and State Pleading Standards", 120 Yale L.J. Online (2010) 109; J. Owen, “A ‘Plausible' Future: Some State Courts Embrace Heightened Pleading after Twombly and Iqbal", 36 North Carolina Central Law Review (2013) 104.

${ }^{34}$ Koppel, supra n. 21, at 1173.

${ }^{35}$ D. Roberts, "The Myth of Uniformity in Federal Civil Procedure: Federal Civil Rule 83 and District Court Local Rulemaking Powers", 8 U.Puget Sound L.Rev. (1985), at 537-555.

${ }^{36}$ Tobias, supra n. 21, at 1395.

${ }^{37}$ Rule 83 provides as follows:

“(a) Local Rules. (1) In General. After giving public notice and an opportunity for comment, a district court, acting by a majority of its district judges, may adopt and amend rules governing its practice. A local rule must be consistent with-but not duplicatefederal statutes and rules adopted under 28 U.S.C. $\$ \S 2072$ and 2075, and must conform to any uniform numbering system prescribed by the Judicial Conference of the United States. A local rule takes effect on the date specified by the district court and remains in effect unless amended by the court or abrogated by the judicial council of the circuit. Copies of rules and amendments must, on their adoption, be furnished to the judicial council and the Administrative Office of the United States Courts and be made available to the public. (2) Requirement of Form. A local rule imposing a requirement of form must not be enforced in a way that causes a party to lose any right because of a nonwillful failure to comply.

(b) Procedure When There Is No Controlling Law. A judge may regulate practice in any manner consistent with federal law, rules adopted under 28 U.S.C. $\S \S 2072$ and 2075, and the district's local rules. No sanction or other disadvantage may be imposed for noncompliance with any requirement not in federal law, federal rules, or the local rules unless the alleged violator has been furnished in the particular case with actual notice of the requirement."

${ }^{38}$ C. Tobias, "Local Federal Civil Procedure for the Twenty-First Century", 77 Notre Dame L.Rev. (2002), at 538.

${ }^{39}$ Tobias, supra n. 21, at 1398 .

40 Tobias, supra n. 21 , at 1404 . 
bankruptcy procedure and appellate procedure in the federal courts. ${ }^{41}$ As one observer puts it, "Rather than uniformity, a high degree of local diversity has been introduced into almost every phase of federal pretrial procedure, including laying of venue, pleading, the use of motions directed to the pleadings, discovery, and even the substitution of alternative methods of dispute resolution for the litigation process itself." 42 As a result, "[a]n increasing array of important procedural issues are now dealt with in federal courts in a local, rather than a national fashion."43

Experts generally have reacted negatively to these developments. Carrington concludes that the local rules create "legal clutter" that obscures the basic commands of the Federal Rules of Civil Procedure, increase costs and create inefficiency and traps for the unwary, while giving an undue advantage to local lawyers. ${ }^{44}$ According to others, these developments mean that "federal practice is more fractured than at any time since the Supreme Court prescribed the original federal rules during 1938;" "45 they mean that "the central accomplishment of uniform federal rules is in serious jeopardy;" 46 and one has gone so far as to say that "the federal judicial system is de-evolving into a collection of largely autonomous units with separate procedural regimes" and "[i]nstead of a unitary federal judicial system, joined together in a common procedural enterprise, each district and each circuit has become its own fiefdom with its own independent rules governing the progress and disposition of litigation." 47

\section{(3) Procedural Diversity Between State Systems and the Federal System}

The third dimension of procedural diversity in the US legal system is state-federal diversity. As noted above, the Process Act of 1789 and the Conformity Act of 1872 required federal courts to follow state procedural rules in actions at law, temporarily resulting in state-federal harmonization in that domain; but there was no similar requirement for actions at equity. After the adoption of the Federal Rules of Civil Procedure, the US federal courts applied those rules rather than state rules in all civil actions, creating disharmony between the rules of civil procedure used in the US federal courts and the diverse rules of civil procedure used in state courts. State-federal harmonization thereafter increased as a growing number of states adopted rules based on the Federal Rules.

However, the Federal Rules have been repeatedly amended, and even states that originally followed the Federal Rules have failed to keep up with those amendments. Moreover, the proliferation of local federal rules means that even state rules of civil procedure that are more or less aligned with the Federal Rules might not be aligned with a given district's local rules — and in states with multiple federal districts with divergent local rules, it simply might not be possible for the state's rules to simultaneously be consistent with the local federal rules of all federal districts within the state. In short, the Federal Rules have become not only a moving target, but multiple moving targets. This instability and failure to maintain uniformity across the US federal districts is at least partly responsible for the decreasing uniformity along the vertical dimension

\footnotetext{
${ }^{41}$ G. Sisk, "The Balkanization of Appellate Justice: The Proliferation of Local Rules in the Federal Courts", 68 U.Colo.L.Rev. (1997) 1; Tobias, supra n. 38, at 558.

${ }^{42}$ Roberts, supra n. 35, at 537-538.

${ }^{43}$ E. Chemerinksy and B. Friedman, "The Fragmentation of Federal Rules", 46 Mercer L.Rev. (1995), at 760.

${ }^{44}$ P. Carrington, “A New Confederacy? Disunionism in the Federal Courts”, 45 Duke L.J. (1996), at 947-948.

45 Tobias, supra n. 38, at 533.

${ }^{46}$ Chemerinsky and Friedman, supra n. 43, at 757.

${ }^{47}$ Sisk, supra n. 41 , at 1-2.
} 
between rules of civil procedure in the federal courts and in state courts. ${ }^{48}$ As Oakley concludes, "Where once the ideal 'one procedure for state and federal courts' was a beacon for procedural reform, its light has dimmed to barely a flicker". 49

\section{(4) Implications for the European Union}

The persistent diversity of rules of civil procedure in the United States - across US states, within the federal courts, and between state and federal courts - suggests that if the EU's goal is harmonization of procedural rules, the United States might not be an ideal model. Nevertheless, there may be lessons to learn from the US experience.

First, the US experience might suggest that the prospect of extensive harmonization across EU member nations is not particularly bright. In the more than 200 years of US history, and notwithstanding a shared legal tradition, procedural harmonization in the United States is far from complete, and may (if some of the commentators cited above are correct) actually be in retreat. Even in the United States, interstate variation in legal culture may be one reason why the harmonizing effects of the Federal Rules of Civil Procedure have not met expectations. ${ }^{50}$ The EU has had less time to lay foundations for harmonization. The Treaty of Rome was signed in 1957. More than half of the EU's members joined in the 1990s and 2000s, making the history of the EU as currently composed even shorter. Moreover, the EU member nations do not have the advantage of a common legal tradition as a point of departure for procedural harmonization. Even using simple traditional categories, EU member nations span at least four different legal families, including the Romanistic, Germanic, English and Nordic families. ${ }^{51}$ Empirical comparative analysis reveals important differences in fundamental legal structures among EU members, including courts, judges and lawyers. ${ }^{52}$ Thus, the US experience might provide evidence supporting those who are doubtful about the likelihood of procedural harmonization in the EU. ${ }^{53}$

But one should not take the comparison too far. In the United States, there has never been a centralized nation-wide effort to harmonize procedure among US state judiciaries. To the extent there is harmonization, it is due primarily to the voluntary adoption of model rules of procedure — such as the Field Code or the Federal Rules of Civil Procedure. Perhaps a centralized EU-driven approach could achieve more harmonization among EU member nations than the "model rules" approach has achieved in the United States. This, however, raises the question of the EU's competence in the domain of civil procedure. Under Article 81(1) of the Treaty on the Functioning of the European Union, "The Union shall develop judicial cooperation in civil matters having cross-border implications...." Some experts argue for an interpretation of "cross-border

\footnotetext{
${ }^{48}$ Koppel, supra n. 21, at 1186.

${ }^{49}$ Oakley, supra n. 28, at 383-384.

${ }^{50}$ Subrin, supra n. 22, at 2046.

${ }^{51}$ K. Zweigert and H. Kötz, Introduction to Comparative Law, 3rd ed., OUP, 1998.

52 A. Uzelac, "Harmonised Civil Procedure in a World of Structural Divergences? Lessons Learned from the CEPEJ Evaluations", in X.E. Kramer and C.H. van Rhee (eds), Civil Litigation in a Globalising World, T.M.C. Asser Press, 2012, at 175-205.

${ }^{53}$ For example, as Kramer, supra n. 1, at 123 puts it: "A full harmonisation of civil procedure at a regional (EU) level [...] is [...] even less likely than full harmonisation of substantive private law." M. Storme, although a strong supporter of harmonisation, concedes that the option to "impose a European system of procedural law, to replace the natural procedural law of each of the Member States [...] is a proposition which is, in my view, totally unrealistic", M. Storme, "Closing Comments: Harmonisation or Globalisation of Civil Procedure?", in X.E. Kramer, C.H. Van Rhee (eds), Civil Litigation in a Globalising World, T.M.C. Asser Press, 2012, 379, at 384. On the other hand, Hess, supra n. 3, at 172 posits that in the long term, in some form, "the elaboration of a coherent European procedural law does seem possible," a conclusion that Storme, at 386 endorses.
} 
implications" that gives it "the broadest possible meaning and, in essence, concerns all types of dispute" because cross-national variation of procedural rules can cause "distortion" within the EU even in disputes that are otherwise purely domestic. ${ }^{54}$ But the predominant understanding appears to be that the power granted to the EU under Article 81 is "limited to international civil procedure" and "does not extend to domestic disputes that have no cross-border aspect to them," and that domestic disputes are therefore "beyond the reach of the legislative powers of the Union." 55

Second, the US experience may be relevant to the question of whether an EU blueprint for harmonization of rules of civil procedure should include the ability of member nations to adopt the equivalent of local rules under Rule 83 of the US Federal Rules of Civil Procedure. Including such a feature might make harmonization by way of EU regulation (if the EU were to acquire the necessary authority) more politically acceptable to EU members and allow rules to be tailored to address particular national challenges or accommodate important national practices. As the US experience indicates, however, there is a risk that opening the door to national rules could lead to a proliferation of such rules, undermining efforts to achieve uniformity across EU members. In any event, if a plan for harmonization in the EU were instead to be based on an EU directive on civil procedure, a counterpart to Rule 83's local rules would likely be redundant since EU members would already be able to develop their own rules to reach the goals set forth in the directive.

\section{(D) The Full Faith And CRedit Alternative}

Even if the United States is not an ideal model for the harmonization of rules of civil procedure, might it nevertheless be a useful model for judicial cooperation among EU members in civil matters? Perhaps. Harmonization of procedural rules is only one way of fostering cooperation. An alternative approach is what I will call "interjurisdictional deference." Rather than insisting on harmonization, interjurisdictional deference tolerates legal diversity and aims to establish judicial cooperation based on the twin foundations of full faith and credit and minimum procedural standards. Full faith and credit requires one jurisdiction to defer to others by recognizing and enforcing the judgments of the courts of other jurisdictions, but only if specified conditions are satisfied. One condition is that the procedural rules producing those judgments conform to agreedupon minimum standards. Even if the United States falls short in terms of harmonization, it is an example of largely successful judicial cooperation in civil matters based on interjurisdictional deference. In fact, there has been a recent flurry of scholarship suggesting various forms of full faith and credit for the EU, ${ }^{56}$ as well as minimum standards of procedure. ${ }^{57}$

\section{(1) Full Faith and Credit}

In the United States, there is a strong and well-established principle of full faith and credit that flows from Article IV, Section 1 of the US Constitution: "Full faith and credit shall be given in each state to the public acts, records, and judicial proceedings of every other state. And the Congress may by general laws prescribe the manner in which such acts, records, and proceedings

\footnotetext{
${ }^{54}$ Storme, supra n. 53.

${ }^{55}$ Wagner, supra n. 4, at 97-98.

56 A. Frackowiak-Adamska, "Time for a European 'Full Faith and Credit Clause", 52 CMLR (2015), 191; M. Lehmann, "Recognition as a Substitute for Conflict of Laws?", in S. Leible (ed), General Principles of European Private International Law, Wolters Kluwer, 2016.

${ }^{57}$ N. Andrews, "Fundamental Principles of Civil Procedure: Order Out of Chaos", in X.E. Kramer, C.H. van Rhee (eds), Civil Litigation in a Globalising World, T.M.C. Asser Press, 2012, 19.
} 
shall be proved, and the effect thereof." A federal statute - 28 USC $\S 1738$ - implements the full-faith-and-credit clause by requiring that all courts in the United States, including both state and federal courts, give full faith and credit to the judicial proceedings of US states. ${ }^{58}$

In the US, full faith and credit is sometimes called an 'iron law' because it can require one state (S2) to enforce another state's (S1) judgment even if the judgment is based on a mistake of fact or law. ${ }^{59}$ If the judgment debtor wishes to challenge the $S 1$ judgment on the merits, it must do so in S1's courts - for example, by appealing to an S1 appellate court - but it cannot do so in S2. There are narrow exceptions to the general rule. Full faith and credit does not require $\mathrm{S} 2$ to enforce an $\mathrm{S} 1$ judgment if the S1 judgment was obtained by fraud or if the S1 court did not have jurisdiction. However, if the $\mathrm{S} 1$ court heard the issue of fraud or jurisdiction and decided against the judgment debtor, the S2 court must give full faith and credit to that decision. ${ }^{60}$

Moreover, the US Supreme Court has stated that there is no "roving public policy exception" to full faith and credit. ${ }^{61}$ According to the Court, "[t]he full faith and credit clause is one of the provisions incorporated into the Constitution by its framers for the purpose of transforming an aggregation of independent, sovereign States into a nation [...] [W]e are aware of [no] considerations of local policy or law which could rightly be deemed to impair the force and effect which the full faith and credit clause [...] require[s] to be given to [a money] judgment outside the state of its rendition." ${ }^{2}$ Although there are occasional suggestions of a limited public policy exception, ${ }^{63}$ "the Supreme Court has not endorsed [a public policy exception] and its precedents seem to negate it." ${ }^{64}$ For these reasons, in the United States, diversity in rules of civil procedure across US states ordinarily will not impair interstate judicial cooperation through recognition and enforcement of foreign judgments.

Has the EU built a sufficiently strong foundation of full faith and credit for judicial cooperation based on interjurisdictional deference? The rules governing the enforcement of a judgment of a court of one EU member (M1) in another EU member (M2) in civil and commercial matters are contained in the recently recast Brussels I Regulation. ${ }^{65}$ Under the Brussels I Regulation, there is a general rule requiring enforcement of an M1 judgment in M2, unless one of the grounds for refusing enforcement listed in Article 45(1) is found to exist:

On the application of any interested party, the recognition of a judgment shall be refused:

\footnotetext{
${ }^{58}$ See 28 USC 1738: 'The [...] judicial proceedings of any court of any [...] State, Territory or Possession [...] shall have the same full faith and credit in every court within the United States and its Territories and Possessions as they have by law or usage in the courts of such State, Territory or Possession from which they are taken.'

${ }^{59}$ W. Reynolds and W. Richman, The Full Faith and Credit Clause: A Reference Guide to the United States Constitution, Praeger, 2005, at 70-73.

${ }^{60}$ W. Richman, W. Reynolds and C. Whytock, Conflict of Laws, 4th ed., Matthew Bender, 2013, at 393-394.

${ }^{61}$ Baker v General Motors 522 US 222, 233-234 (1998).

${ }^{62}$ Baker v General Motors (n 27) 233-234 (citations omitted).

${ }^{63}$ See, eg, Restatement (Second) of Conflict of Laws $\S 103$ : 'A judgment rendered in one State of the United States need not be recognized or enforced in a sister State if such recognition or enforcement is not required by the national policy of full faith and credit because it would involve an improper interference with important interests of the sister State'; Reading \& Bates v Baker Energy Resources 976 SW 2d 702 (Tex App 1998).

${ }^{64}$ S. Symeonides, "Choice of Law in the American Courts in 2013: Twenty-Seventh Annual Survey", 62 Am.J.Comp.L. (2014), at 319.

${ }^{65}$ Regulation No 1215/2012 of 12 December 2012 on jurisdiction and the recognition and enforcement of judgments in civil and commercial matters (recast), OJ 2012 L 351 (hereinafter Brussels I Reg).
} 
(a) if such recognition is manifestly contrary to public policy (ordre public) in the Member State addressed;

(b) where the judgment was given in default of appearance, if the defendant was not served with the document which instituted the proceedings or with an equivalent document in sufficient time and in such a way as to enable him to arrange for his defence, unless the defendant failed to commence proceedings to challenge the judgment when it was possible for him to do so;

(c) if the judgment is irreconcilable with a judgment given between the same parties in the Member State addressed;

(d) if the judgment is irreconcilable with an earlier judgment given in another Member State or in a third State involving the same cause of action and between the same parties, provided that the earlier judgment fulfils the conditions necessary for its recognition in the Member State addressed; or

(e) if the judgment conflicts with: (i) [the special jurisdictional provisions of] Sections 3, 4 or 5 of Chapter II where the policyholder, the insured, a beneficiary of the insurance contract, the injured party, the consumer or the employee was the defendant; or (ii) [the exclusive jurisdiction provisions of] Section 6 of Chapter II.

In one respect, the Brussels I Regulation may require an even more robust form of full faith and credit than the US principle of full faith and credit because neither fraud nor lack of personal jurisdiction is an express ground for refusing recognition and enforcement. ${ }^{66}$ For two reasons, however, these differences should not be exaggerated. First, as just noted, under the US law of full faith and credit, S2 must give full faith and credit to an S1 court's rulings on fraud or jurisdiction. Second, unlike the US approach to full faith and credit, the EU approach has an explicit public policy exception. The public policy exception is generally understood as being very narrow, ${ }^{67}$ but it nevertheless suggests that the EU's requirement of "full faith and credit" is not as strict as the US requirement. Indeed, some experts argue that the public policy exception can be understood as providing a "safety net" that can allow M2 to refuse enforcement of an M1 judgment where M1 failed to provide certain procedural rights — including those fair trial rights assured by Article 6(1) of the European Convention on Human Rights ${ }^{68}$ — which would go beyond the grounds for refusal expressly available under the US law of full faith and credit.

\section{(2) Fundamental Principles of Procedure}

By itself, however, full faith and credit is not a satisfactory alternative to harmonization of procedural rules. After all, it would be offensive to the protection of fundamental rights and politically unacceptable to blindly recognize and enforce the judgments of other jurisdictions regardless of the procedural rules followed. For this reason, agreement on fundamental principles of procedure or "minimum standards" is also essential. The United States has a well-developed body of nation-wide minimum standards for civil procedure, based primarily on the due process

\footnotetext{
${ }^{66}$ Except pursuant to Article 45(1)(e), where the judgment conflicts with the Brussels I Regulation's special jurisdictional provisions designed to protect weak parties — but even then, Article 45(2) provides that M2 shall be bound by the findings of fact on which M1 based its jurisdiction.

${ }^{67}$ P. Stone, EU Private International Law, 2nd ed., Edward Elgar Publishing, 2010, at 239.

${ }^{68}$ X.E. Kramer, "Cross-border Enforcement in the EU: Mutual Trust versus Fair Trial? Towards Principles of European Civil Procedure", 2 IJPL (2011) 202, 219: 'A safety net for the violation of fair trial principles is provided [by the Brussels I Reg] at the enforcement level through the ground of refusal relating to public policy'.
} 
clauses of the US Constitution and their interpretation and application by US courts, most notably the US Supreme Court. ${ }^{6}$

Although it has not had the 200 years of constitutional history that the United States has had to develop minimum procedural standards, the EU — and to some extent Europe more generally has been making rapid progress. The "constitutional roots" for such standards can be found in both Article 47 of the EU Charter of Fundamental Rights ${ }^{70}$ and Article 6 of the European Convention on Human Rights. ${ }^{71}$ As European experts on civil procedure have argued, these provisions, together with their interpretation and application by the Court of Justice of the European Union and the European Court of Human Rights, can provide a point of departure for the development of EU-wide minimum standards. ${ }^{72}$ Synthesized and restated, these standards might eventually be embodied in a set of Principles of European Civil Procedure. ${ }^{73}$ For example, Andrews has proposed a set of fundamental principles of procedure, which he organizes into four categories: regulating access to court and to justice, ensuring fairness of the process, maintaining a speedy and effective process, and achieving just and effective outcomes. ${ }^{74}$ Such a project could also build on the seminal work of Storme ${ }^{75}$ and the ALI/UNIDROIT project on Principles of Transnational Civil Procedure (although the latter, having taken into account US procedure, might not be most appropriate for an EU-specific project). These principles might, in turn, serve as the centerpiece of an EU directive, defining the result to be achieved - namely, rules of civil procedure that meet the specified minimum standards - but allowing each member nation to develop those rules for itself. ${ }^{76}$ This two-step process, whereby the EU adopts a directive setting forth standards and the directive is then implemented by the member states in accordance with the standards, has been taken in other fields of EU law. ${ }^{77}$

\section{(3) Implications for the EU}

In short, whereas there are reasons to conclude that harmonized rules of civil procedure for all EU members are unlikely, the alternative of judicial cooperation based on US-style interjurisdictional

\footnotetext{
${ }^{69}$ E. Chemerinsky, Constitutional Law: Principles and Policies, 4th ed., Aspen Publishers, 2011, at ch. 7.

${ }^{70}$ Article 47 of the EU Charter of Fundamental Rights ("Right to an effective remedy and to a fair trial") provides: "Everyone whose rights and freedoms guaranteed by the law of the Union are violated has the right to an effective remedy before a tribunal in compliance with the conditions laid down in this Article. Everyone is entitled to a fair and public hearing within a reasonable time by an independent and impartial tribunal previously established by law. Everyone shall have the possibility of being advised, defended and represented. Legal aid shall be made available to those who lack sufficient resources in so far as such aid is necessary to ensure effective access to justice."

${ }^{71}$ Article 6(1) of the European Convention ("Right to a fair trial") provides: "In the determination of his civil rights and obligations or of any criminal charge against him, everyone is entitled to a fair and public hearing within a reasonable time by an independent and impartial tribunal established by law. Judgment shall be pronounced publicly but the press and public may be excluded from all or part of the trial in the interests of morals, public order or national security in a democratic society, where the interests of juveniles or the protection of the private life of the parties so require, or to the extent strictly necessary in the opinion of the court in special circumstances where publicity would prejudice the interests of justice."

${ }^{72}$ Hess, supra n. 3, at 161; S. Prechal, "The Court of Justice and Effective Judicial Protection: What Has the Charter Changed?" in C. Paulussen et al. (eds), Fundamental Rights in International and European Law, T.M.C. Asser Press, $2016,143$.

${ }^{73}$ Kramer and van Rhee, supra n. 7, at 15.

74 Andrews, supra n. 57.

${ }^{75}$ M. Storme (ed), Approximation of Judiciary Law in the European Union, Martinus Nijhoff Publishers, 1994.

${ }^{76}$ Article 288 TFEU: "To exercise the Union's competences, the institutions shall adopt regulations, directives, decisions, recommendations and opinions. A regulation shall have general application. It shall be binding in its entirety and directly applicable in all Member States. A directive shall be binding, as to the result to be achieved, upon each Member State to which it is addressed, but shall leave to the national authorities the choice of form and methods."

${ }^{77}$ Hess, supra n. 3, at 160 .
} 
deference might be in reach. Such an approach would be a lesser imposition than full-fledged harmonization on the procedural autonomy of EU member states. ${ }^{78}$ In addition, interjurisdictional deference accommodates legal diversity (within the limits of minimum standards) which, from a law and economics perspective, may allow satisfaction of a greater number of diverse preferences and enable learning effects. ${ }^{79}$ It does not require that perspective to agree that "where different procedural structures turn out to be equally effective, fair, transparent and user-friendly, the pluralism of procedural forms may be ... considered as desirable, just as harmony may be better achieved by polyphonic voices than by voices chanting in unison." $" 80$

Of course, this would not be a perfect solution. Persistent procedural differences, with their implications for substantive outcomes, would persist with this model and would risk creating incentives for forum shopping and reverse forum shopping, which is one consequence of procedural diversity in the United States. Nevertheless, in the United States, well-developed principles of full faith and credit and procedural due process combine to make it possible to speak of a reasonably stable and coherent "US legal system." The same might be achievable in the EU.

One potential barrier to this approach is that EU members currently appear to lack the level of "mutual trust" required for a sufficiently robust principle of full faith and credit. In the EU, the principle of mutual trust has played an animating role in private international law since at least the early 1990s. In Sonntag v. Waidmann, a 1993 case before the European Court of Justice, Advocate General Darmon stated in his opinion that "[t]he principle of the recognition of judgments is based on the Member States' mutual trust in their respective legal systems and judicial institutions. This trust allows the Member States to waive their internal rules on the recognition and enforcement of foreign judgments." 81 Reinforcing this understanding, the recast Brussels I Regulation explicitly links the abolition of exequatur to mutual trust: "Mutual trust in the administration of justice in the Union justifies the principle that judgments given in a Member State should be recognised in all Member States without the need for any special procedure [...] As a result, a judgment given by the courts of a Member State should be treated as if it had been given in the Member State addressed." 82

However, it is unclear that mutual trust has developed EU-wide to the point where US-style full faith and credit — without a public policy "safety net" — would be viable or appropriate. Although each country admitted to the EU must satisfy rigorous conditions for membership, and although the European Convention on Human Rights and the EU Charter of Fundamental Rights provide minimum standards of fair trial, the European Commission has found that corruption is a

\footnotetext{
${ }^{78}$ D. Galetta, Procedural Autonomy of EU Member States: Paradise Lost?, Springer, 2010, at 168; Hess, supra n. 3 , at 168.

${ }^{79}$ L. Visscher, "A Law and Economics View on Harmonisation of Procedural Law", in X.E. Kramer and C.H. van Rhee (eds), Civil Litigation in a Globalising World, T.M.C. Asser Press, 2012, at 74-78.

${ }^{80}$ Uzelac, supra n. 52, at 204.

${ }^{81}$ Opinion of Advocate General Darmon in CJEU, case C-172/91, Sonntag/Waidmann, ECLI:EU:C:1992:487, at para. 71-72.

${ }^{82}$ Recital 26 of Brussels I Recast. See also Pamela Kiesselbach, at 8 (explaining that the proposal to abolish exequatur "is premised upon the assumption of a high level of mutual trust and confidence in the maturity of judicial systems across the EU"); X.E. Kramer, "Procedure Matters: Construction and Deconstructivism in European Civil Procedure," 33 Erasmus Law Lectures (2012), at 18: "Based on this pillar [mutual trust], the European Commission wishes to abolish the permission of courts for the enforcement of judgments rendered in another EU Member State. The idea is that if there is full mutual trust, this permission (called exequatur) is no longer required".
} 
significant problem in EU member states. ${ }^{83}$ One observer argues that enlargement has exacerbated these concerns:

The issue of corruption is a sensitive one in the EU, and is usually avoided in the legislative discussions on private international law. But the existence of corruption in general is acknowledged, and was put on the political agenda. Recent reports from Transparency International and the EU have revealed that corruption is a major problem in many member states, and that it has increased over the past few years. Corruption exists in every member state, but the reports make clear that the expansion of the EU to countries with weaker institutions requires serious attention. In this light, [some claims about] mutual trust may be a little too optimistic. ${ }^{84}$

And according to another observer: "Differences in [expectations of users of the justice system] in Europe are not only huge, they are also not sufficiently diagnosed and monitored. The extremes, such as the established human rights violations regarding fairness and length of proceedings, are only symptoms and tentative indications. It is certain that in the current state of affairs neither in Greater Europe nor in the EU can citizens approach courts and authorities in other States with the expectation of receiving the same standards of legal protection, both regarding its fairness and its effectiveness." 85

\section{(E) The Politics of Procedural ReForm}

A third reason why the US experience might not be an ideal model for the harmonization of civil procedure in the EU is that the process of procedural rulemaking is often quite politicized in the United States. A more technical approach might be possible, and more desirable, in the EU.

The conventional wisdom is that initially, at least, the values underlying civil procedure in the United States were considered to be apolitical — "values of administrative design, such as efficiency (understood narrowly as minimizing administrative cost), simplicity, and flexibility." 86 However, as civil litigation in the United States became increasingly viewed as an instrument for advancing public as well as private interests — promoting, for example, civil rights, consumer welfare, and environmental protection - it became more difficult to think of procedure as merely technical. ${ }^{87}$ One scholar argues that politics came to procedural reform as early as the Field Code's spread in the mid-to-late 1800s, noting that legislation based on the code "[i]n many places [...] came to be festooned with provisions sought by special interests." 88 Today "recognition of the

\footnotetext{
${ }^{83}$ See European Commission, EU Anti-Corruption Report, COM(2014) 38 final, available at http://ec.europa.eu/dgs/homeaffairs/what-we-do/policies/organized-crime-and-human-trafficking/corruption/anti-corruption-report/index_en.htm (last visited 16 June 2014).

${ }^{84}$ X.E. Kramer, "Private International Law Responses to Corruption: Approaches to Jurisdiction and Foreign Judgments and the International Fight Against Corruption", in International Law and the Fight against Corruption, Advisory Report for the Dutch Royal Society of International Law, No. 139, Asser Press, 2012, at 139. See also R. Arenas Garcia, "Abolition of Exequatur: Problems and Solutions", 12 Yrbk Priv Intl L (2010) 351, at 372: "[M]utual trust is a legal obligation, but it can also be seen as a fact. In other words: the authorities of one Member State must trust the authorities of the other Member States; but do they really trust them?".

${ }^{85}$ Uzelac, supra n. 52, at 204.

${ }^{86}$ R. Bone, "The Process of Making Process: Court Rulemaking, Democratic Legitimacy, and Procedural Efficacy”, 87 Geo.L.J. (1999), at 896.

${ }^{87}$ Bone, supra n. 86, at 902.

${ }^{88}$ Marcus, supra n. 15, at 165.
} 
power of procedure to advance substantive agendas has led to increased political pressures. Interest groups lobby rulemakers and legislators to create or preserve procedural advantages." 89

Business-oriented interest groups have influenced all three branches of the US federal government in ways that increasingly limit court access and private enforcement of legal rights. Recent examples include the Private Securities Litigation Reform Act of 1995 (federal legislation limiting investor protection suits against corporations), the 2015 amendments to the Federal Rules of Civil Procedure (limiting discovery, among other amendments), and US Supreme Court decisions that some argue circumvented the authorized federal rulemaking process by changing procedures to facilitate summary judgment and impose stricter pleading requirements.

It is difficult to characterize these and other recent changes other than as pro-defendant and probusiness. But whether these changes impose inappropriate limits on court access or provide appropriate protections against frivolous litigation is in the eye of the beholder. The essential point is that it is well understood that changes in rules of civil procedure have distributive consequences - they affect the ability of plaintiffs to seek judicial enforcement of rights and the exposure of defendants to the costs of litigation and of potential judgments. While politics is expected to influence legislation, evidence of interest group capture in recent procedural changes introduced by the unelected US Supreme Court ${ }^{90}$ and produced by the federal rulemaking process ${ }^{91}$ is more disconcerting.

In the United States the political salience of procedural change may be greater than in most EU members. This is because of the role of litigation in the US as a means for private parties to enforce legal rights in areas that affect the public interest, such as consumer and labor rights, environmental protection, racial discrimination, and antitrust. ${ }^{92}$ Because civil litigation is an important regulatory tool in the US, those favoring regulation may be more likely to favor a higher degree of court access and access to discovery, whereas those with a more deregulatory bent may be more likely to advocate tighter restrictions. As one expert who has been deeply involved in federal rulemaking puts it, recent business-oriented changes to the Federal Rules of Civil Procedure "weaken[] the enforcement of public laws by private citizens [and] thus conform[] to the deregulation or tortreform politics favored by many business interests." 93 The same expert links the defendantoriented tilt in recent procedural changes to a political shift from a view of litigation as an appropriate means of regulating business in the public interest to an increasingly anti-regulation outlook. ${ }^{94}$

Because civil litigation is not as well established as a method of law and policy reform in EU members nations as it is in the United States, perhaps in its own harmonization efforts the EU can more effectively manage interest group capture of the rulemaking process than the United States. Perhaps it is possible to "strike an EU-wide balance on the rights of claimants and defendants." 95

\footnotetext{
${ }^{89}$ Michalski, supra n. 33, at 113.

${ }^{90}$ P. Carrington, "Politics and Civil Procedure Rulemaking: Reflections on Experience", 60 Duke L.J. (2010), at 663-664.

${ }^{91}$ P. Moore, "The Anti-Plaintiff Pending Amendments to the Federal Rules of Civil Procedure and the Pro-Defendant Composition of the Federal Rulemaking Committees", 83 U.Cin.L.Rev. (2015) 1083; L. Mullenix, "Discovery in Disarray: The Pervasive Myth of Pervasive Discovery Abuse and the Consequences for Unfounded Rulemaking", 46 Stan.L.Rev. (1994) 1393.

92 Subrin, supra n. 22, at 2050.

${ }^{93}$ Carrington, supra n. 90 , at 600 .

${ }^{94}$ Carrington, supra n. 90, at 606-608.

${ }^{95}$ Carrington, supra n. 90, at 606-608.
} 
On the other hand, "the balance between pro-claimant/creditor and pro-defendant/debtor approaches may differ from Member State to Member State, depending on the deeper political and axiological choices underlying civil procedure. Indeed, the law of civil procedure is not a standalone legal field, but rather 'is embedded in a web of legal, political, economic and social expectations, some of which the procedural system helps to create." $" 96$ If this is correct, then it would seem that procedural rules are intrinsically political, and that a process of procedural harmonization in the EU would ultimately become politicized. By allowing more procedural diversity, the alternative path to judicial cooperation-interjurisdictional deference based on full faith and credit and minimum standards of procedure - might best manage the impact of politics by avoiding a centralized EU rulemaking process that might be especially susceptible to specialized interest group influences (a risk suggested by the US federal rulemaking process) and fostering competition between different sets of national procedural rules. ${ }^{97}$

\section{(G) CONCLUSION}

The US example, although sometimes viewed as a model of procedural harmonization, in fact illustrates the limits of harmonization, as well as harmonization's ebbs and flows. Diversity in politics, local practices and legal culture, might mean that a single model for state and federal courts is unlikely in the United States. The EU would surely face similar or even greater challenges if it were to embark on full-fledged efforts toward harmonization of members' rules of civil procedure. However, the EU is already on its way toward what for the near term, at least, would seem to be a more attainable objective: a fairly robust form of full faith and credit, coupled with increasingly well-developed minimum standards of civil procedure, that can foster judicial cooperation based in interjurisdictional deference. The result could be a cohesive and wellfunctioning "European legal system" notwithstanding significant differences in national rules of civil procedure. The challenge — if the US is any guide - will be how to navigate the politics of procedural reform in a way that will produce rational and coherent EU minimum standards and national rules that serve the public good.

\footnotetext{
${ }^{96}$ Mańko, supra n. 8, at 4.

${ }^{97}$ Visscher, supra n. 79, at 79.
} 